Jahangirnagar University J. Biol. Sci. 8(1): 17-23, 2019 (June)

\title{
Food and feeding behaviour of Chestnut-tailed Starling, Sturnia malabarica at Jahangirnagar University Campus, Bangladesh
}

\author{
Md. Touhidur Rahman*, Shamia Farhana Shoma, Mohammed Mostafa Feeroz and \\ Md. Kamrul Hasan \\ Department of Zoology, Jahangirnagar University, Savar, Dhaka-1342, Bangladesh
}

\begin{abstract}
Food and feeding behaviour of Chestnut-tailed Starling, Sturnia malabarica were studied at Jahangirnagar University Campus, Bangladesh, from August 2016 to March 2017. A total of 414 observations were made on the feeding maneuver and it was noted that they were omnivorous consuming $67.15 \%$ animal diet compared to $20.53 \%$ plant diet.They predominantly consumedinsect larvae(39\%) followed by beetles (16\%), nectar (14\%), food wastes $(12 \%)$, fruits $(7 \%)$, dragonflies $(7 \%)$, damselflies $(3 \%)$, and worms $(2 \%)$. Among the five types of feeding modes recorded,hang-upmode $(37.92 \%)$ was major feeding technique in Chestnuttailed Starling while pecking mode $(6.76 \%)$ was least used. Rain tree (Samanea saman) $(33.76 \%)$ followed by White siris (Albizia procera) (30.55\%) was recorded as the most utilized foraging plant while mostly preferred perching height by Chestnut-tailed Starling was $6-9 \mathrm{~m}$ (44.9\%) followed by $3-6 \mathrm{~m}(31.6 \%)$.
\end{abstract}

Key words: Chestnut-tailed Starling, Sturnia malabarica, food and feeding, JU campus

\section{INTRODUCTION}

Diet plays fundamental rolein bird's life history and constitutes the basic ecology of a species (Duraes \& Marini, 2003). Studies on the feeding ecology of birds is important to understandcommunity structure, resource use patternand their co-existence in a particular habitat (Asokan \& Ali, 2010; Kaur \& Kler, 2018). Knowledge on feeding habit helps to identify the habitat characters and determine the status of the species and ecosystem. It also provides necessary information for the conservation and management of species and ecosystems (Asokan \& Ali, 2010).

Sturnidae (Starlings \& Mynas), a common song bird family, is widely distributed throughout the world. They are well knownas bio-controlling agents in agricultural world and have been introduced in many countries (Craig \& Feare, 2010). Bangladesh is the home of 12 species of sturnids including Chestnut-tailed Starling (Sturnia malabarica) (Khan, 2018). They occupy similar habitats throughout the country. Due to having diverse habitats like permanent water bodies (artificial lakes and ponds), marshy areas, woodlands, grasslands, bushes, cultivated lands etc., Jahangirnagar University Campus (JUC) is rich in bird species. Chestnut-tailed Starling is very common here and shares the same feeding and breeding habitat with three other sturnid species - Common Myna (Acridotheres tristis), Jungle Myna (Acridotheres fuscus) and Asian Pied Starling (Gracupica contra) (Begum, 2006; Mohsanin \& Khan, 2009).

\footnotetext{
* Corresponding author. E-mail: trtareqju@gmail.com
} 
Despite being common resident species, biology of Chestnut-tailed Starling is not well documented and detailed studies on the feeding ecology is still scarce in Bangladesh. Very littleis known about feeding habits of this species from previous studies (Begum, 2006; Jaman \& Sahreen, 2004). Hence, the present study was conducted to investigate the food and feeding behavior of Chestnut-tailed Starling at JUC with special reference to dietary preference, feeding modes, foraging plants and perching height preference.

\section{MATERIALS AND METHODS}

Study area: The study was conducted between August 2016 and March 2017 atJahangirnagar University Campus. It is situated at $32 \mathrm{~km}$ north of Dhaka city $\left(23^{\circ} 88 \mathrm{~N}\right.$ and $90^{\circ} 26^{\mathrm{E}} \mathrm{E}$ ) and is about700 acres in area. The climate of this area is characterized by three main seasons: summer (March to May), monsoon (June to October) and winter (November to February).

Food and feeding data: Data on food and feeding behaviour of Chestnut-tailed Starlingat JUC were collected through direct observation. A total of 173 hours was spent at the study area for data collection and only birds with confirmed food items were recorded.Individual birds were observed systematically and their diet, feeding modes, foraging plants and perching heights (height at which the bird perched while feeding) were noted carefully. Feeding modes of $S$. malabarica were classified into following five categories (Remsen \& Scoot, 1990).

Hang-up: Hangingon vertical or horizontal substrate, including acrobatic movements, with head up.

Hang-down: Hanging on vertical or horizontal substrate, including acrobatic movements, with head down.

Gleaning: Picking food item from a nearby substrate, including the ground, without extending legs and neck completely.

Pecking: Driving the beak against the substrate to remove some of the exterior of the substrate.

Aerial: Flying into air to catch flying prey.

Perching heightswere grouped into four categories: 0-3m, 3-6m, 6-9m and 9-12m. The heights of the plants were visually estimated (Narayana et al., 2014).

Food items consumed by Chestnut-tailed Starlingwere identified through direct observation.A pair of binoculars (Bushnell, $8 \times 42 \mathrm{~mm}$ ) and photographstaken by Canon $700 \mathrm{D} / 55-250$ camera wereused to identify the food items those could not be identified by naked eyes particularly the flying insects and the food items of higher canopy.

From the data collected we determined and calculated percent use of food items and different foraging variables used by Chestnut-tailed Starling. The chi-square test was used to determine whether there are significant variations in monthly utilization of food items by Chestnut-tailed Starling. 


\section{RESULTS AND DISCUSSION}

Food items: A total of 414 observations were made on food and feeding behaviour of Chestnut-tailed Starling at JUC. They were omnivorous and the diet constituted $67.15 \%$ animal matter, $20.53 \%$ plant matter and $12.32 \%$ food wastes. Animal diets included both larval and adult forms of insects, and worms while plant diets included fruits and nectar (Fig. 1). Based on the observations, insect larvae (39\%) were predominant food items consumed by Chestnut-tailed Starling followed by beetles (16\%), nectar $(14 \%)$, food wastes (12\%), fruits (7\%), dragonflies (7\%), damselflies $(3 \%)$, and worms (2\%) (Fig.1).It was observed that insect larvae constituted $57.91 \%$ of animal diet.This ismay be due to the availability of diversegroup of insectsparticularly butterfliesat the study area and easy access of birds to inactive larval form. Jaman \& Sahreen (2004) and Begum (2006) also reported insects as major animal diet of Chestnuttailed Starling.Among the plant diets, Chestnut-tailed Starling preferred nectar over fruits. However, monthly utilization of food items did not differ significantly $\left(\chi^{2}=64.14, \mathrm{P}>0.05\right.$, $\mathrm{df}=49$ ) (Fig. 2). Consumption of insect larvae was consistently highest throughout the study period except in February.In February, the birds were mostly found to consume nectar as many flowers were in bloom at this time. Many factors like seasons, weather, availability of food, breeding season and interspecific competition influence the foraging behaviour of birds (Kelly, 1998; Gokula \& Vijayan, 2007; Asokan \& Ali, 2010). It is worth mentioning that during the study period, monthly average temperature at JUC ranged between $21^{\circ} \mathrm{C}$ and $30^{\circ} \mathrm{C}$ whereas monthly average humidity varied from $56.66 \%$ to $88.92 \%$. Average highest rainfall was recorded in August $(87 \mathrm{~mm}$ ) while no rainfall was recorded in December, January and February (Source: Department of Department of Geography and Environment, Jahangirnagar University).

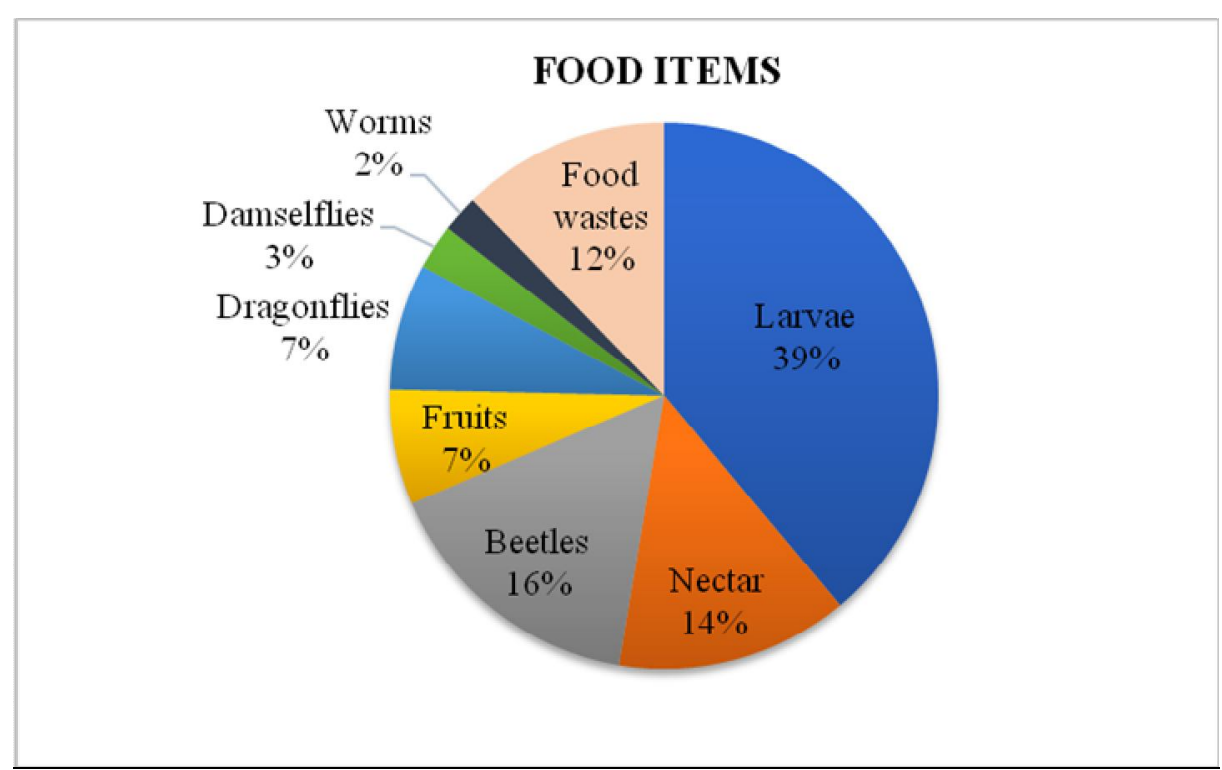

Fig. 1. Proportions of different food itemsconsumed by Chestnut-tailed Starlingat JUC $(\mathrm{N}=\mathbf{4 1 4})$ 


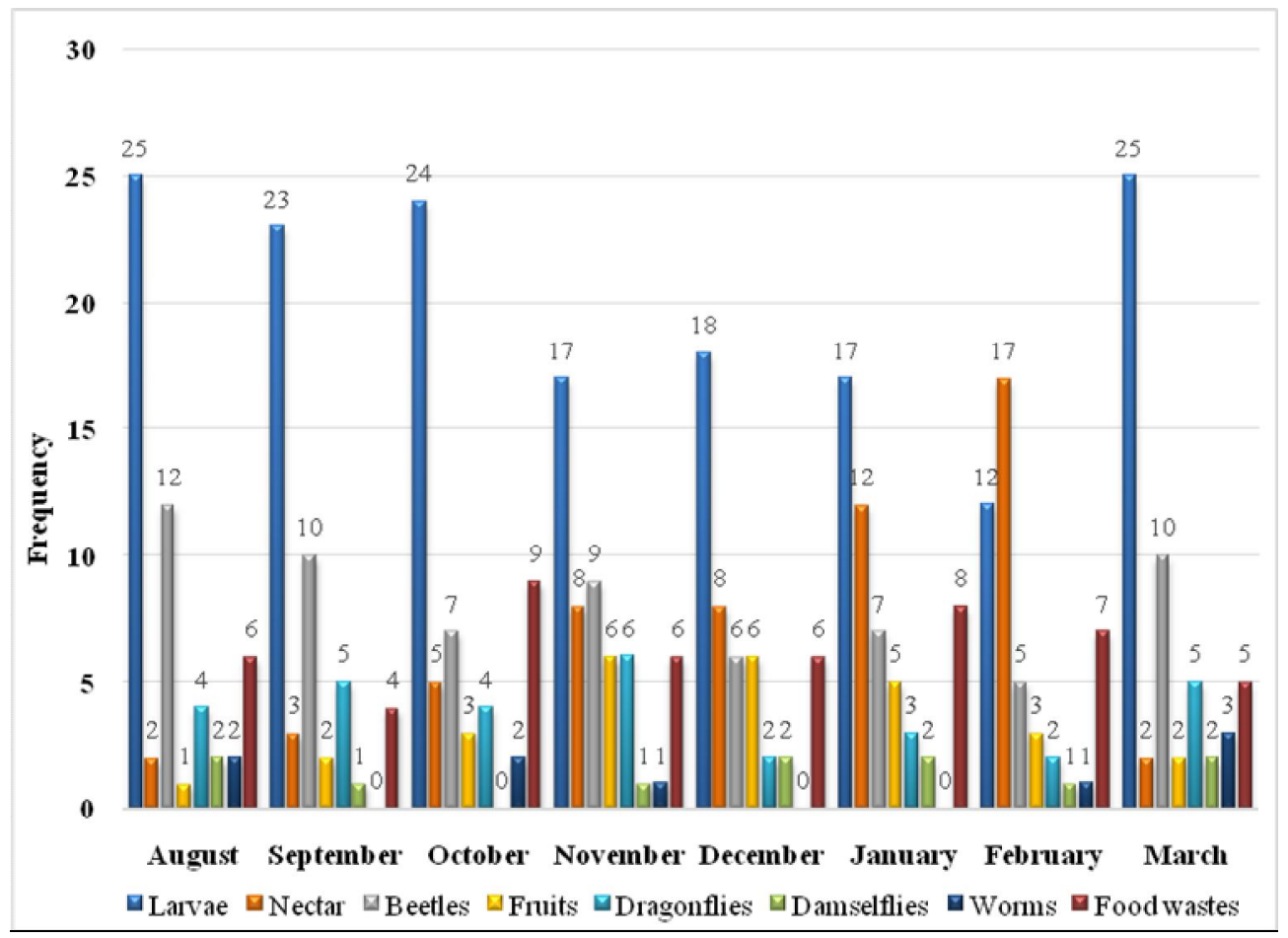

Fig. 2. Monthly variations in utilization of different food items by Chestnut-tailed Starling at JUC $(\mathbf{N}=\mathbf{4 1 4})$

Modes of feeding: In present study, five types of feeding modesof Chestnut-tailed Starling were recorded. Among them, thestarlings mostly used hang-up (37.92\%) mode followed by hang-down (30.43\%) whereas pecking mode was least used (6.76\%) (Fig. 3). Hang-up and hang-down were mainly used to capture insect larvae and also to take flower nectar. This species particularly captured the larvae by hanging down when a larva was under the leaf or stem or branch. Aerial mode $(11.35 \%)$ was used to capture the flying insects like dragonflies and damselflies.Pecking mode was observed while taking insects from fruits and barks. Another important feeding method of Chestnut-tailed Starling was gleaning (13.53\%). Some insects, fruits, and ground food such as food wastes and worms were taken by using this method. Gleaning is one of the major forms of feeding behaviour used by ground and foliage searching birds as gleaning has least rate of energy expenditure compared to the other behaviour (Remsen \& Scott, 1990). However, Recher \& Davis, 1998; Gokula \& Vijayan, 2000; Murakami, 2002; Asokan \& Ali, 2010 mentioned that the use of feeding technique of birds depends on the morphological characteristics of the species, onthe habitat type and the availability of food items. 


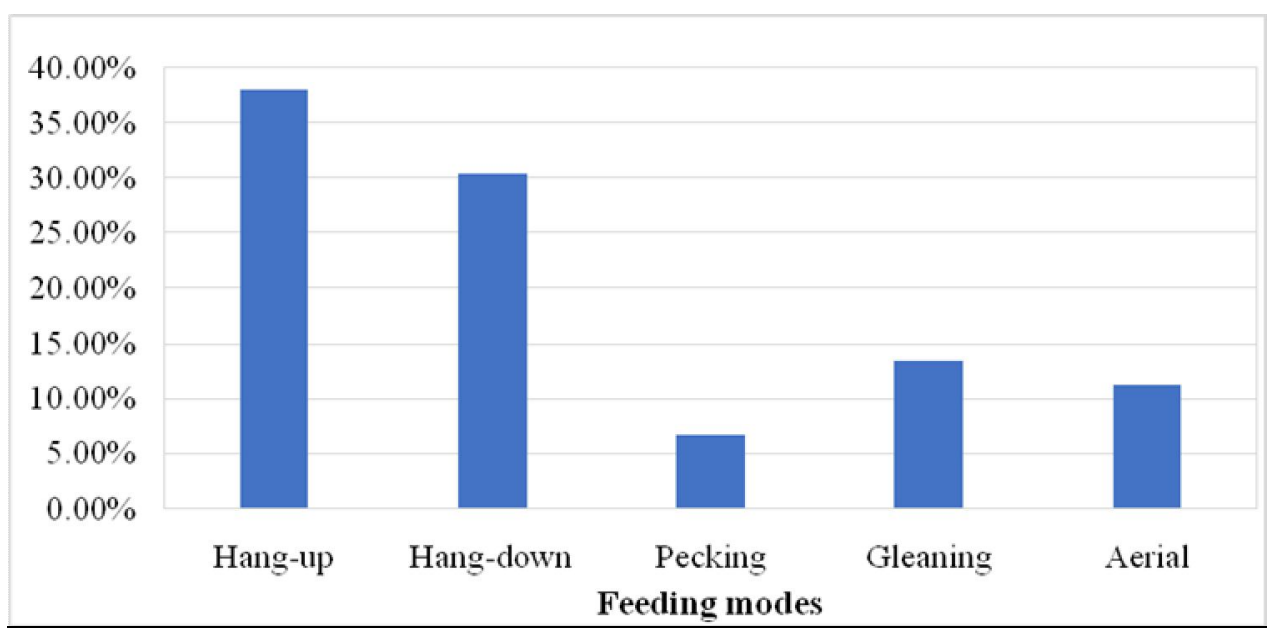

Fig. 3. Proportions of different feeding modes by Chestnut-tailed Starling at JUC $(\mathrm{N}=414)$

Foraging plants: Although there are a great variety of plants in Jahangirnagar University Campus (Hossain et al., 1995), Chestnut-tailed Starlings were found to be selective in foraging. During the study period, they were observed to forage only ten species of plants (Table 1).Among them, the starlings mostly foraged on Samanea saman (33.76\%) followed by Albizia procera (30.55\%).These species were common in JUC and mostly foraged for insect larvae. Ficus benghalensis (12.54\%) and Madhuca indica (1.29\%) were mainly preferred for fruits while Butea monosperma $(9.00 \%)$ was preferred for nectar. In February when Butea monosperma in full bloom, flocks of Chestnut-tailed Starling were often found to forage the trees for nectar. The previous study at JUC by Begum (2006) reported that Chestnut-tailed Starling consumed figs, berries and fruits of Acacia while no foraging behaviour of S. malabarica was recorded on Acacia in the present study.

Table 1. Plant species used by Chestnut-tailed Starling for feeding purposesat JUC

\begin{tabular}{|c|c|c|c|c|}
\hline $\begin{array}{c}\text { Common } \\
\text { name }\end{array}$ & Scientific name & Family & $\begin{array}{c}\text { Frequency of } \\
\text { feeding }(\%)\end{array}$ & Food items \\
\hline Rain tree & Samanea saman & Fabaceae & 33.76 & Insects (larva or adult) \\
\hline White siris & Albizia procera & Fabaceae & 30.55 & Insects (larva or adult) \\
\hline Banyan & Ficus benghalensis & Moreceae & 12.54 & $\begin{array}{l}\text { Fruits, Insects (larva or } \\
\text { adult) }\end{array}$ \\
\hline $\begin{array}{l}\text { Flame of } \\
\text { the forest }\end{array}$ & Butea monosperma & Fabaceae & 9.00 & Nectar \\
\hline Jackfruit & Artocarpas heterophyllus & Moraceae & 5.47 & Insects (larva or adult) \\
\hline $\begin{array}{l}\text { Spanish } \\
\text { cherry }\end{array}$ & Mimusops elengi & Sapotaceae & 3.54 & Fruits \\
\hline $\begin{array}{l}\text { Bengal } \\
\text { almond }\end{array}$ & Terminalia catappa & Combretaceae & 1.93 & Fruits \\
\hline Mahua & Madhuca indica & Sapotaceae & 1.29 & Fruits \\
\hline Jujube & Zizyphus mauritiana & Rhamnaceae & 0.96 & Fruits \\
\hline Black plum & Syzygium cuminii & Myrtaceae & 0.96 & Fruits \\
\hline
\end{tabular}


Perching heights: Chestnut-tailed Starling preferred mostly 6 to $9 \mathrm{~m}$ perching height (44.9\%) to collect their food while 3-6m (31.6\%) was their next preference (Fig. 4). $S$. malabarica was chiefly arboreal and availability of food like insect larvae and flower nectar allowed the species to choose this height at JUC. The present study showed similarity with the findings of Jaman \& Sahreen (2004) and Begum (2006). While Begum (2006) found that the Chestnut-tailed Starling was strictly arboreal feeder rather than ground feeder, Jaman \& Sahreen (2004) reported that the species mainly found on upper canopy of the trees to feed on insects. Different species prefer to forage at different heights and it varies with regions depending on the habitat characteristics. Asokan \& Ali (2010) reported that Common myna mostly forage on ground.Narayana et al. (2015) found that Black Drongo preferred a perching height of 9-12min Nalgonda District of Andhra Pradesh, India while the study conducted by Asokan \& Ali (2010) showed that Black Drongo fed at 0-6m in Nagapattinam District of Tamil Nadu, India. Sivakumaran \& Thiyagesan (2003) found that Indian Roller preferred to perch at heights of 3-9m for locating the preys.

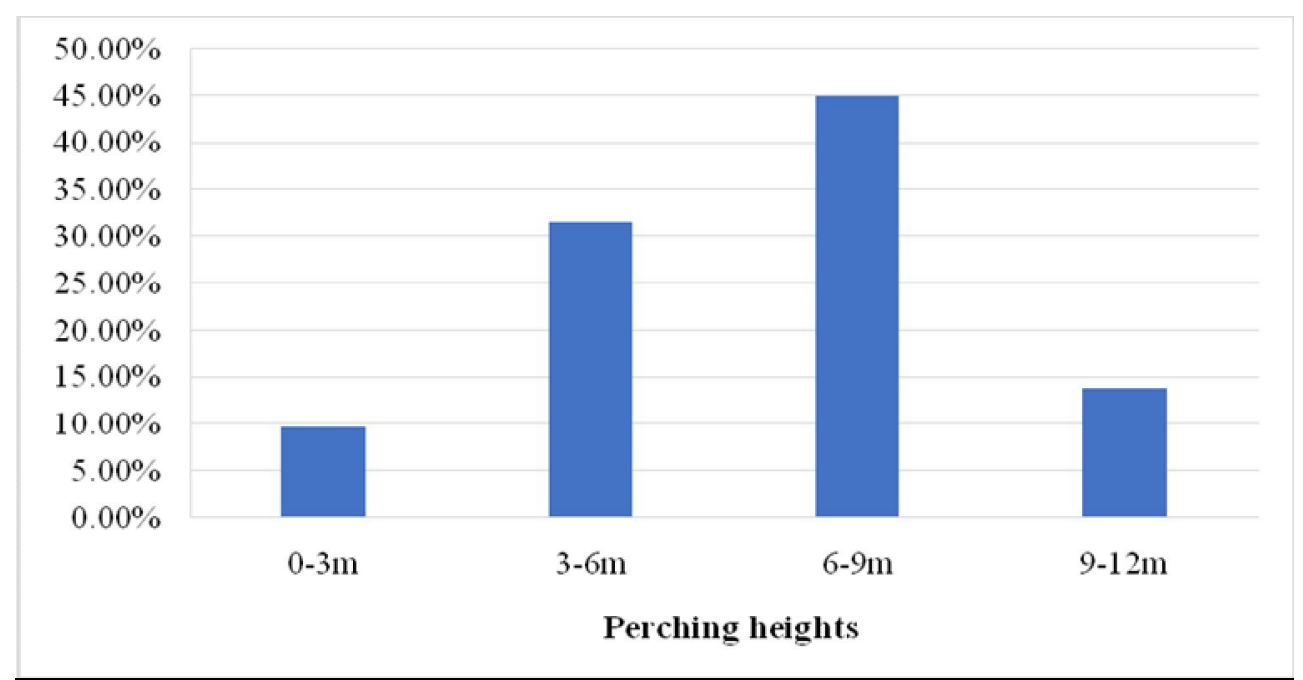

Fig. 4. Perching heights used by Chestnut-tailed Starling at JUC (N=414)

In conclusion, our findings demonstrate that Chestnut-tailed Starling was an omnivorous bird having insect larvae as staple diet, and thus playing an important role in ecosystem. In addition, they were predominantly arboreal feeder and large trees like Rain tree, white siris and Banyan were their major forging plants. Therefore, protection and conservation of these trees at JUC is important for their survival. However, season and ambient temperature influence the feeding behaviour of birds (Asokan \& Ali, 2010). The present study was mainly conducted in non-breeding season of the species. Study on feeding ecology of Chestnut-tailed Starling at JUC including their breeding season is recommended as the availability of food and energy expenditure during this time may result variations in the consumption of food and foraging behavior (Welty \& Baptista, 1988; Hambly et al., 2007). 


\section{REFERENCES}

Asokan, S. and Ali, A.M.S. 2010. Foraging behavior of selected insectivorous birds in Cauvery Delta region of Nagapattinam District, Tamil Nadu, India. Journal of Threatened Taxa, 2(2): 690-694.

Begum, S. 2006. Feeding and breeding behaviour of different species of mynas found at Jahangirnagar University Campus. Jahangirnagar University project report 2005-2006 (Unpublished), Jahangirnagar University, Savar, Dhaka.

Craig, A. and Feare, C. 2010. Starlings and mynas. A \& C Black, London.

Duraes, R. and Marini, M.A. 2003. An evaluation of the use of tartar emetic in the study of bird diets in the Atlantic Forest of southeastern Brazil. J. field Ornithol. 74(3): 270-280.

Gokula, V. and Vijayan, L. 2000. Foraging pattern of birds during the breeding season in thorn forest of Mudumalai wildlife sanctuary, Tamil Nadu, South India. Tropical Ecology, 41: 195-208.

Gokula, V. and Vijayan, L. 2007. Foraging strategies of birds in partitioning of food resources in dry deciduous forest of Mudumalai Wildlife Sanctuary, Tamil Nadu, India. Journal of Scientific Transaction in Environment and Technovation, 1(1): 36-42.

Hambly, C., Markman, S., Roxburgh, L. and Pinshow, B. 2007. Seasonal sex-specific energy expenditure in breeding and non-breeding Palestine sunbirds Nectarinia osea. Journal of Avian Biology, 38(2): 190-197.

Hossain, A.B.M.E., Khan, S.A. and Islam, M.A.1995. An inventory of plant diversity in relation to ecology and environment of Jahangirnagar University: vegetational composition and their taxonomic identity. Bangladesh Journal of Life Science, 7: 95-103.

Jaman, M. and Sahreen, N. 2004. Ecology and breeding biology of Chestnut-tailed Starling, Sturnus malabaricus (Gmelin, 1789). Ecoprint: An International Journal of Ecology, 11(1). https://doi.org/10.3126/eco.v11i1.142

Kaur, G. and Kler, K.T. 2018. Feeding behaviour and perching preferences of black drongo (Dicrurus macrocercus) in Ludhiana district (Punjab). Journal of Entomology and Zoology Studies, 6(4): 232-239.

Kelly, J. 1998. Behaviour and energy budgets of Belted Kingfishersin winter. Journal of Field Ornithology, 69: 75-84.

Khan, M.M.H. 2018. Photographic Guide to the Wildlife of Bangladesh. Arannnayk Foundation, Dhaka, Bangladesh.

Mohsanin, S. and Khan, M.M.H. 2009. Status and seasonal occurrenceof the birds in Jahangirnagar University campus. Bangladesh Journal of Life Science, 21(1): 29-37.

Murakami, M. 2002. Foraging mode of four insectivorous bird species under temporally varying resources distribution in a Japanese deciduous forest. Ornithological Science, 1: 63-69.

Narayana, B.L., Rao, V.V. and Reddy, V.V. 2014. Foraging behaviour of Black Drongo (Dicrurus macrocercus) in Nalgonda district of Andhra Pradesh, India. The Bioscan, 9 (2): 467-471.

Recher, H.F. and Davis, W.E. 1998. The foraging profile of a Wandoo woodland avifauna in early spring. Australian Journal of Ecology, 23: 514-527.

Remsen, J.V. and Scoot, K.R.1990. A classification scheme for foraging behavior of birds in terrestrial habitats. Studies in Avian Biology, 12: 144-160.

Sivakumaran, N. and Thiyagesan, K. 2003. Population, diurnal activity patterns and feeding ecology of the Indian Roller Coracias benghalensis. Zoos' Print Journal, 18(5): 10911095.

Welty, J.C. and Baptista, L.F. 1988. The Life of Birds. 4th edition. W.B. Saunders Co., College Park, N.Y. 